\title{
FIFTH INTERNATIONAL PEDIATRIC NEPHROLOGY SYMPOSIUM
}

Combined

Committees, Program, and Abstracts

\author{
Cohosted By
}

The Children's Hospital of Philadelphia

St. Christopher's Hospital for Children

The Hilton Hotel and

The Children's Hospital of Philadelphia Philadelphia, Pennsylvania

October 6-10, 1980 


\section{FIFTH INTERNATIONAL PEDIATRIC NEPHROLOGY SYMPOSIUM}

President Alan B. Gruskin

\section{SPONSORS}

International Paediatric Nephrology Association

American Society of Pediatric Nephrology

European Society of Paediatric Nephrology

Japanese Society of Pediatric Nephrology

Nephrology Section of the American Academy of Pediatrics

Society for Pediatric Research

American Society of Nephrology

National Kidney Foundation

Southeastern Pennsylvania Chapter
Secretary-General Michael E. Norman

\section{PHILADELPHIA ORGANIZING COMMITTEE}

H.J. Baluarte

D. Cornfeld

M. Cote

J.W. Duckett

B. Faulkner

J. Foreman

R. Gottlieb

L. Hiner

M. Polinsky

J. Prebis

M.W. Schwartz
INTERNATIONAL ORGANIZING COMMITTEE

G. Arbus (Toronto)

G. Arneil (Glasgow)

C. Gianantonio (Buenos Aires)

I. Greifer (New York)

R. Habib (Paris)

I. Houston (Manchester)

E. Lieberman (Los Angeles)

H. Obling (Essen)

T. Sakai (Kanagawa-Ken)

\section{PROGRAM CONTENT COMMITTEE}

A. Aperia (Stockholm)

T.M. Barratt (London)

H. Boichis (Tel Hashomer)

P. Jose (Washington)

J. Lewy (New Orleans)

D. McCredie (Melbourne)

A. Michael (Minneapolis)

0. Oetliker (Bern)

J. Pascual (San Juan)

D. Potter (San Francisco)

SOCIAL COMMITTEE
K. Baluarte
S. Bonnem
J. Cornfeld
L. Hipp
L. Dawson
B. McCray
M. Duckett
E. Morris
L. Foreman
A. Prebis
M. Raphaely
P. Gruskin
S. Schwartz 


\section{PLENARY SESSIONS}

TUESDAY MORNING, OCTOBER 7, 1980
A. PLENARY SESSION - I
Opening Remarks A.B.Gruskin
President, 5 IPNS Philadelphia
Welcome to Philadelphia
M.E. Norman, Secretary-Genera 15 IPNS Philadelphia

B. STATE OF THE ART ADDRESSES:

Immunologic Systems Involved in Renal Disease

A.F. Michael Minneapolis

Problems In the immunopathology of Nephritis

J.S. Cameron London

The Physiology of the Child's

Kidney

C.M. Edelmann, Jr. New York

WEDNESDAY MORNING, October 8, 1980

A. PLENARY SESSION - II

Review of Previous Day's Symposia

G. Gordillo, Chairperson,

Mexico City

B. STATE OF THE ART ADDRESSES:

Functions of the Renal Glomerulus

B.M. Brenner Boston

The Pathology of Glomerular Disease-

An Update

R. Habib

Paris
THURSDAY MORNING, OCTCBER 9, 1980

A. PLENARY SESSION - III

Review of Previous Day's Symposia

K. Scharer, Chairperson

Heidelberg

B. STATE OF THE ART ADDRESS:

The Parathyroid Gland

S.G. Massry

Los Angeles

FRIDAY MORNING, OCTOBER 10, 1980
A. PLENARY SESSION - IV
Review of Previous Day's Symposia W.W. McCrory, Chairperson New York
B. STATE OF THE ART ADDRESS:
Renal Tubular Acidosis
J.R. Soriano
Bilbao 


\section{SYMPOSIA}

TUESDAY AFTERNOON, OCTOBER 7, 1980

1. IMMUNOLOGIC MECHANISMS INVOLVED IN KIDNEY DISEASE

Immunologic Mechanisms-Introductory Comments

R.L. Vernier, Chairperson, Minneapolis

Mechanism of Immune Complex Injury

W.G. Couser Boston

The Mesangium and Glomerulonephritis

S.M. Mauer Minneapolis

Cell-Mediated Immunity in Renal Disease

A.D. Steinberg Bethesda

2. APPLICATION OF MICROTECHNIQUES TO THE STUDY OF RENAL FUNCTION

Analysis of Segmental Nephron Functions in Vivo and in Vitro

M.F. Horster, Chairperson, Munich

The Use of Isolated Tubules in The Study of Regulation of Cell Volume

M.A. Linshaw

Kansas City

Application of Microtechniques to the Study of Renal Function:Toad Bladder
S.A. Mendoza
La Jolla

Micropuncture in Developmental Renal Physiology:Its Potential and Limits
A. Spitzer
New York

3. INTERSTITIAL NEPHRITIS

Interstitial Nephritis-A Pediatric

Disorder

B. Pollara, Chairperson, Albany

The Clinical Features of Chronic

Interstitial Nephritis

T.G. Murray

Philadelphia

Pathology of Interstitial Nephritis

I.B. Elfenbein

Philadelphia

Experimental Models of Interstitial Nephritis

J.R. Hoyer

Torrance
WEDNESDAY MORNING, OCTOBER 8, 1980

1. GLOMERULAR DISORDERS

Multiple Concepts of Focal Segmental Glomerulonephritis

I. Greifer, Chairperson, New York

Berger Disease-Clinical and

Immunopathologic Data

M. Levy Paris

Schönlein-Henoch Nephritis

A Problem or Not?

R.H.R. White

Birmingham

Membranoproliferative Glomerulonephri Classification and Treatment

C.D. West

Cincinnati

2. CLINICAL ASPECTS OF CHILDHOOD HYPERTEN

Plasma Catecholamines in Normal Child and Children With Essential Hypertens J.G. Mongeau, Chairperson, Montreal

Uric Acid Regulation in Hypertensive Children

J.W. Prebis Philadelph

Clinical Correlations in Childhood Hypertension

E. Lieberman

Los Angele:

Renal Vein Renin Determinations in

Evaluating Hypertensive Children

M.J. Dillon

London

3. URINARY TRACT INFECTION AND REFLUX-PART

Urinary Tract Infection and Reflux

J.W. Duckett, Chairperson, Philadelphi

Pathogenesis of Reflux Nephropathy

P. Ransley

London

The Nosology of Urinary Tract Infectic in Children

G.A. Richard

Gainesville

Localization of Urinary Tract Infectic

J. Winberg 
SCIENTIFIC PROGRAM - FIFTH INTERNATIONAL PEDIATRIC NEPHROLOGY SYMPOSIUM

SYMPOSIA

VESDAY AFTERNOON, OCTOBER 8, 1980

- URINARY TRACT INFECTION REFLUX-PART II

J.W. Duckett, Chairperson, Philadelphia

Report of International Vasicoureteral Reflux Study

H. Olbing

Essen

Surgical Management of Reflux

$R$. Jeffs Báltimore

Natural History of Reflux

J. Smellie London

- CONTROLLED CLINICAL TRIALS-PROGRESS REPORTS

Clinical Trials-Introductory Comments

H.L. Barnett, Chairperson, New York

International Collaborative Study of

Kidney Disease in Children-A Progress

Report

D.I. Goldsmith New York

Clinical Study of $\mathrm{HB}_{\mathrm{S}}$ Antigenemia Associated Nephropathy in Children

F. Yamashita Kurma

Cyclophosphamide vs Chlorambucil in the Treatment of Frequently Relapsing and Steroid-Dependent Nephrotic Syndrome H.P. Krohn Hannover

Anticoagulant Therapy vs No Treatment in the Hemolytic-Uremic Syndrome

W.C. Proesmans Leuven

Principles and Practices of Controlled Clinical Trials
C.L. Meinert
Baltimore

\section{DIALYSIS THERAPY IN CHILDREN}

Long-Term Problems of Hemodialysis M.J.Broyer, Chairperson, Paris

Hemodialysis or Peritoneal DialysisViable Options

D.E. Potter San Francisco

Developmental Aspects of Peritoneal Dialys is

A.Y. Elzouki Benghazi

The Peritoneal Membrane as a Source of Nutrients

N.G. DeSanto Naples

THURSDAY MORNING, OCTOBER 9, 1980

1. JUVENILE RENAL OSTEODYSTROPHY

$25(\mathrm{OH}) \mathrm{D}_{3}$ in the Treatment of Juvenile Renal Osteodystrophy

M.E. Norman, Chairperson, Philadelphia

The Clinical Syndrome of Renal Os teodys trophy
I.B. Houston
Manchester

1,25-Dihydroxy Vitamin $D_{3}$ in the Treatment of Juvenile Renal Osteodystrophy
R.W. Chesney
Madison

The Spectrum of Skeletal Manifestations in Renal Osteodystrophy
0 . Mehts
Heidelberg

2. TRANSITIONAL PHYSIOLOGY

Transitional Physiology

P.A. Jose, Chairperson, Washington

Renal Function in the Fetal Animal

E.S. Moore

Chicago

Adaptation of the Infant to an External Milieu

B.S. Arant, Jr. Dallas

Renal Function in the Newly Born Infant
A.C. Aperia
Stockholm 


\section{SYMPOSIA}

3. THE KIDNEY IN SYSTEMIC DISEASE

The Kidney in Systemic Disease:

An Overview

L.B. Travis, Chairperson, Galveston

The Kidney Following Cardiac Surgery

T.M. Barratt London

The Kidney in Sickle Cell Anemia

J. Strauss Miami

The Kidney in Cystinosis

J.W. Foreman Philadelphia

4. NUTRITION

Current Problems in Providing Nutrients to Individuals With Kidney Disease

C.Giordano, Chairperson, Naples

Amino Acids and Protein Metabolism

C. Chantler London

Is Energy Deficiency a Part of the Uremic Syndrome?

M.A. Holliday San Francisco

Lipid Metabolism

A. Drukker Jerusalem

ERIDAY MORNING, OCTOBER 10, 1980

1. RENAL PATHOLOGY

Current Issues in Pediatric Renal

Pathology

J. Bernstein, Chairperson, Royal Oak

Pathology of Membranoproliferative Glomerulonephritis

$A, J$, McAdams Cincinnati

Circulating Immune Complexes-

Systemic Lupus Erythematosus

E.J. Lewis

Chicago

Focal Glomerulosclerosis

D.R. Turner

London
2. DIAGNOSTIC TECHNIQUES

Ultrasound Evaluation of the Child's Kidney

G.C. Arneil, Chairperson, Glasgow

Radionuclide Imaging in the Evaluation of Pediatric Renal Disorders

H.T. Harcke

Philadelphia

Use of Isotopes to Evaluate Renal Function M.D. Blaufox New York

Applications of Radiographic Techniques to Evaluate Renal Disorders

H.M. Pollack

Philadelphia

3. TRANSPLANTATION

Immune Therapy Following Transplantation

R.N. Fine, Chairperson, Los Angeles

Topics In Transplantation Immunology R.B. Ettenger Los Angeles

Recurrence of Disease in Transplanted Kidneys

E.P. Leuman Zurich

Hypertension in Children With Kidney Transplants

J.R. Ingelfinger Boston

FRIDAY AFTERNOON, OCTOBER 10, 1980

1. TUBULAR TRANSPORT

Transport Defects-Current Issues

S. Segal, Chairperson, Philadelphia

Amino Acid Transport

J. Brodehl Hannover

Hydrogen Ion Transport

E. McSherry

San Francisco

Phosphate Transport

Z.S. Agus

Philadelphia 


\section{SCIENTIFIC SESSIONS - FIFTH INTERNATIONAL PEDIATRIC NEPHROLOGY SYMPOSIUM}

\section{SYMPOSIA}

\section{THERAPEUTICS}

Prevention of Progressive Renal Failure in Familial Mediterranian Fever

H. Boichis, Chairperson, Tel-Hashomer

Management of Resistant Hypertension-The Role of Minoxidil

P.R. Lewy

Chicago

Chlorambucil Therapy in The Nephrotic Syndrome

H.J. Baluarte

Philadelphia

Anticoagulant Therapy

J.M. Bergstein

Indianapolis

3. HORMONES

The Renin-Angiotensin System in Healthy Infants and Children

K.J. Van Acker, Chairperson, Antwerp

Growth Failure, ESRD, and Somatomedin

J.E. Lewy New Orleans

An Approach to Study the Role of Prostaglandins

O.H. Oetliker Bern

Corticosteroids

0 . Koskimies Helsinki

4. CHILDHOOD DISORDERS:METABOLIC ALKALOSIS

Bartter Syndrome-An overview

P.L. Calcagno, Chairperson, Washington

Pathogenesis of Neo-Mull-Soy(R) Alkalosis

H.L. Harrison Louisville

Metabolic Alkalosis From a Chloride

Deficient Formula-Renal Histology

S. (NMN) Roy III Memphis

Prostaglandins, Low Chloride or Something

Else?

J.R. Salcedo

Washington
5. WORK IN PROGRESS - PART I

T. Sakai, Chairperson, Kanagawa-Kan

Asymptomatic Hematuria and Proteinuria in School Children-Correlation Between Urinary Findings and Renal Pathology T. Kitagawa Tokyo

Polyamines for Nephrologists

R.A. Campbe 11

Portland

Combined Report on Regular Dialys is and Kidney Transplantation in Children in Europe, 1979

R.A. Donckerwolcke Utrecht

Immune Mechanisms in Nephrosis

A.M. Robson St. Louis

Plasma Exchange in the Management of Rapidly Progressive Nephritis

A.J. Rees

London

6. WORK IN PROGRESS - PART II

Ongoing Studies in Children with ESRD

G.S. Arbus, Chairperson, Toronto

Clinical Studies of Calcium Metabolism J.C.M. Chan Richmond

The Stressed Neonatal Kidney

J.P. Guignard Lausanne

Anthropologic Studies of Hypertensive Children

S. Katz

Philadelphia 
SCIENTIFIC PROGRAM - FIFTH INTERNATIONAL PEDIATRIC NEPHROLOGY SYMPOSIUM

FREE PAPER SESSIONS

TUESDAY MORNING, OCTOBER 7, 1980

1. Glomerulonephritis

2. Renal Involvement in Systemic Disease

3. Dialys is

4. Physiology I

5. Coagulation

6. Poster Session:

Hypertension \& Metabolism (all day)
WEDNESDAY AFTERNOON, OCTOBER 8, 1980

1. Nephrotic Syndrome II

2. Physiology II

3. Renal Os teodystrophy

4. Drugs \& The Kidney II

5. UTI-Urology II

6. Metabolism
TUESDAY AFTERNOON, OCTOBER 7, 1980

1. Clinical Nephrology I

2. Transitional Nephrology

3. Hypertens ion I

4. UTI-Urology I

5. Renal Failure I

6. Pathology
THURSDAY MORNING, OCTOBER 9, 1980

1. Immunology II

2. Transitional Nephrology II

3. Genetics

4. Transplantation

5. UTI-Urology III

6. Immunosuppressive Therapy

7. Poster Session: Glomerular Disorders (all day)
WEDNESDAY MORNING, OCTOBER 8, 1980

1. Acid Base-Renal Electrolyte I

2. Nephrotic Syndrome I

3. Hypertension II

4. Drugs \& The Kidney I

5. Immunology I

6. Renal Failure II

7. Poster Session: Renal Failure (a1l day)
FRIDAY MORNING, OCTOBER 10, 1980

1. Clinical Nephrology II

2. Idiopathic Hematuria

3. Dialys is \& Transplantation Sys temic Aspects

4. Acid Base-Renal Electrolyte II

5. Immunology III

6. Nephrotic Syndrome III

7. Poster Session: Physiology \& Infection (al1 day) 